\title{
CRITICALITY ASSESSMENT OF ENERGY INFRASTRUCTURE
}

\author{
Juozas AUGUTIS ${ }^{\mathrm{a}, \mathrm{b}}$, Benas JOKŠAS ${ }^{\mathrm{b}}$, Ričardas KRIKŠTOLAITIS, \\ Inga ŽUTAUTAITÉ ${ }^{a}$ b \\ a'Department of Mathematics and Statistics, Vytautas Magnus University, \\ Vileikos g. 8, 44404 Kaunas, Lithuania \\ ${ }^{\mathrm{b}}$ Laboratory of Nuclear Installations Safety, Lithuanian Energy Institute, \\ Breslaujos g. 3, 44403 Kaunas, Lithuania
}

Received 27 May 2013; accepted 22 November 2013

\begin{abstract}
After the last major accidents in the energy sector of the last decade (USA and Canada (2003), India (2012), Russian-Ukrainian (2009)), energy infrastructure criticality assessment has become one of the most important issues. It has become the topical subject of the economy and national security in all countries. There is no single measure unit for the assessment of critical infrastructure with respect to "interdependency" among critical infrastructure sectors. This paper proposes to use criticality of infrastructure element as a measure to assess the importance of considered element to the normal activity of all sectors of infrastructure. The pilot numerical simulation of heat and electricity infrastructure was performed to demonstrate the implementation of the application of developed method for the assessment of infrastructure functionality and criticality.

Keywords: critical infrastructure, criticality, functionality, heat and electricity sectors, cascading effect.

Reference to this paper should be made as follows: Augutis, J.; Jokšas, B.; Krikštolaitis, R.; Žutautaite, I. 2014. Criticality assessment of energy infrastructure, Technological and Economic Development of Economy 20(2): 312-331.
\end{abstract}

JEL Classification: C15, A11, C80, C63, E22.

\section{Introduction}

Nowadays the national and economic security of the Country is dependent on sustainable operations infrastructure in the country inside and in neighbour countries. Most of the country's infrastructure, particularly energy infrastructure, is integral within the country and neighbour countries. Incidents in one or more infrastructure sectors could cause enormous

Corresponding author Benas Jokšas

E-mail: joksas@mail.lei.lt 
serious consequences locally or/and globally. The disturbance of some infrastructure sectors could lead cascading effects in the related infrastructure sectors. For instance, the Northeast blackout in north USA and Canada (2003) affected approximately 10 million people in Ontario and 45 million people in eight United States; the blackout in India (July 2012) was the largest power outage in history, the outage affected over 620 million people; the Russian-Ukrainian gas dispute (2009) affected 18 countries in European Union and Balkan region. Therefore, this important area attracts a lot of attention, and research works are performed at all levels: regional, national and international level.

The solution of the infrastructure security problem is comprised of two parts:

1) Identification of the critical elements of the infrastructure, the development of security plans;

2) The analysis and assessment of infrastructure criticality.

The Member States of the European Union already have these lists of identification of critical infrastructure elements (The Council of the European Union 2008). Lithuania has identified critical infrastructure elements of energy system and prepared security and emergency accidents' management plans for infrastructure system (e.g. Natural gas transmission system, Kaunas HPP, etc.)

However failures or accidents of one critical infrastructure have a high negative effect on other infrastructure systems (cascading effect). Therefore, infrastructure models are essential to simulate various situations and assess the influence of element failure (accident or element loss) to other elements of the system.

As usually scientists analyse infrastructures using risk analysis methods (Kjølle et al. 2012; Theoharidou et al. 2010; Utne et al. 2011; Wibowo, Mohamed 2010). It enables to identify the most risky location or elements in the infrastructure. Authors usually use fault trees analysis or event tress analysis. These methods enable to perform topological analysis of infrastructure and as a result risk index of infrastructure assessment is obtained.

There are several papers that presented the analysis of criticality of infrastructure (Canto-Perello et al. 2013; Chou et al. 2012; Theoharidou et al. 2010). In these papers authors analysed separate parts of infrastructure (railway system or underground tunnel). They analysed infrastructure elements that could be critical at local scale or national scale. The authors used a risk analysis method to prepare a critical success factor or criticality level of infrastructure.

The other aim of infrastructure research is to analyse interdependencies of partial infrastructure system (Holden et al. 2013; Chai et al. 2011; Skea et al. 2012; Xia et al. 2013; Theoharidou et al. 2010; Wang et al. 2012). In these papers the authors analysed systems of interdependencies between electricity substation, water treatment plant and water supply for consumers. Other authors analysed oil and gas industries or railway infrastructure (Chai et al. 2011; Xia et al. 2013). The authors presented a network model designed for interdependencies between infrastructure systems at different scales. The system of infrastructure is considered a network. The authors suggested that optimal performance of the network under normal and extreme conditions may be found by minimizing the cost of commodity flow. The authors used Monte Carlo method for realization of simulation in their investigations.

The vulnerability analysis of infrastructure is one of the issues being considered by the authors (van der Vleuten, Lagendijk 2010; Eusgeld et al. 2009; Murray, Grubesic 2012; 
Ryu et al. 2009; Nan et al. 2013; Bompard et al. 2009; Xia et al. 2013; Wang et al. 2012). The approaches for modelling interdependent technical infrastructures are proposed in the papers. The authors used a graph theory for modelling fictional electrified railway network or power transmission grids. These approaches are comprised of several systems and interdependencies between the systems. They presented how the model can be employed in a vulnerability analysis.

The analysis of critical components or critical location identification as well as edge attack strategies are other issues which are investigated by the authors (Wang et al. 2013, 2012; Eusgeld et al. 2009; Murray, Grubesic 2012; Bompard et al. 2009; Zio, Golea 2012; Kjølle et al. 2012; Yan et al. 2010). Some authors used power and gas pipeline systems as examples and they analysed critical components in these systems.

The identification of the most critical elements of electrical transmission system is analysed by other authors (Johansson et al. 2013; Trucco et al. 2012; Wang et al. 2012). Graph theory for topological analysis of system is used as main tool for modelling infrastructure system and analysing vulnerability of interdependent infrastructure systems. Researches introduced how to estimate network's dynamic functionality and proposed an alternative to the electrical reliability degree, the expected electrical distance could be used to evaluate the importance of different network components.

Some papers proposed a method for assessing the holistic criticality (Theoharidou et al. 2010; Sabio et al. 2012; Hassan et al. 2012; Amouzandeh et al. 2011). The authors introduced the formal definition of interdependencies between different infrastructures and their respective sectors. The authors used risk analysis method for criticality assessment of infrastructure system. Separation layers of interdependencies are proposed in these papers as well. Some of the authors used multi-objective optimization and principal component analysis.

The criticality analysis of infrastructure elements is helpful to design or improve the infrastructures in the long run or short term. The criticality assessment of infrastructure taking into consideration elements functionality is essential. The cascading failures in some infrastructure sectors are important for criticality analysis as well.

One of the main systems of the Country infrastructure is district heat system. It is very important in the countries where cold climate (e.g. Lithuania) and many buildings belong to the low energy efficiency classes (or so called shortly "low energy efficiency building") (Venckus et al. 2012). It is very important to assess the criticality of heat infrastructure, despite the fact that the research is conducted along with building renovation (e.g. Brauers 2012). As an example of assessment of heating network is presented in the paper (Augutis, Matuzienè 2012).

Energy infrastructure is closely related to innovative solutions, such as smart houses (passive houses), directly to the consumer (Kaklauskas et al. 2012; Tanaka et al. 2012). Some disturbance in the electrical supply system, could seriously affect the entire IT system.

A general energy infrastructure model, descriptions of elements concept (generation technologies, supply technologies, etc.) are presented in this paper. Therefore, the infrastructure of the power and heat generation and gas pipeline systems were analysed in more details with regard to interdependency between separate elements of infrastructure systems. 


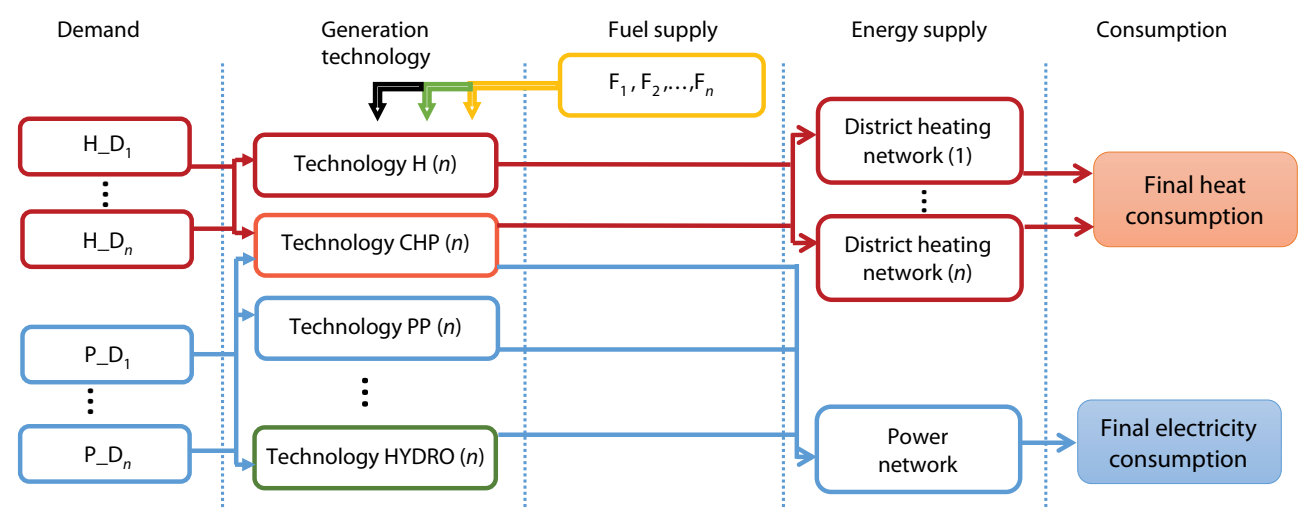

Fig. 1. The scheme of energy infrastructure

The authors propose the developed method for the assessment of infrastructure functionality and criticality. Various assessment criteria (e.g. various technical characteristic, risk index, connections of various relationship between system elements, pollution or economics index) can be integrated into this method. This is the pilot research and the aspect of economical and environmental assessment of critical infrastructure will be analysed in the future researches.

Different types of power and heat generation technologies are described in more detail. The criticality indicator estimates of considering part of energy infrastructure were obtained by applying developed method for the assessment of infrastructure criticality. The infrastructure that represents the energy sector was analysed in this paper. The energy infrastructure could be comprised of consumers, generation technologies, fuel supply technologies, energy supply technologies, etc. The simplified scheme of the energy infrastructure is presented in Fig. 1.

In this paper authors analyse the relationship connections between gas supply system and electricity and heat systems. The renewable sources of energy, biomass CHP will be analysed in future research.

\section{Energy generation technology costs}

Support of acceptable or reached criticality level may be ensured by modifying energy sector, updating the aged technologies. In essence, concept of criticality is an economical category as well. The method and model created in this article enable to verify various energy system scenarios, to introduce or replace energy generation and supply technologies with the new ones and compare their criticality level and estimate the expenses for reducing criticality. Prices of the main technologies, which may be referred to, are presented in the International Energy Agency study (International Energy Agency 2010). In 2010, the study “Projected Costs of Generating Electricity - 2010 Edition" was published. The study highlighted the main results of the activities carried out in 2009, i.e. calculating the costs of generating baseload electricity from nuclear and fossil fuel thermal power stations as well as the costs of generating electricity from a wide range of renewable technologies, some of them with variable or intermittent production. The study focuses on the expected plant-level costs of baseload electricity generation by power plants that could be commissioned by 2015 . 
On the basis of this study some significant conclusions can be drawn. At discount rate 5\% nuclear energy are rather competitive (Table 1). It should be emphasized that these results encompass a carbon price of USD 30 per tonne of $\mathrm{CO} 2$, and there are great uncertainties concerning cost of carbon capture, which has not yet been deployed on an industrial scale. However, at discount rate $10 \%$ from cost perspective the cheapest energy generation source would be Combined Heat Power plant (Table 1).

Table 1. Levelised costs of electricity (USD/MWh) for European countries

\begin{tabular}{lccccccc}
\hline & Nuclear & $\begin{array}{c}\text { Coal with } \\
\text { CC(S) }\end{array}$ & $\begin{array}{c}\text { Coal without } \\
\text { CC(S) }\end{array}$ & Gas & $\begin{array}{c}\text { Onshore } \\
\text { wind }\end{array}$ & $\begin{array}{c}\text { Offshore } \\
\text { wind }\end{array}$ & CHP \\
\hline & \multicolumn{7}{c}{$5 \%$ discount rate } \\
\hline Median & 61.83 & 88.29 & 82.13 & 89.51 & 104.43 & 140.82 & 59.58 \\
\hline Weighted average & 62.19 & 83.44 & 78.11 & 87.01 & 96.50 & 139.86 & 64.89 \\
\hline Minimum & 43.49 & 68.06 & 50.44 & 57.75 & 63.39 & 128.72 & 24.12 \\
\hline Maximum & 81.65 & 102.59 & 120.01 & 118.77 & 162.9 & 188.21 & 103.34 \\
\hline & \multicolumn{7}{c}{$10 \%$ discount rate } \\
\hline Median & 101.49 & 136.12 & 100.22 & 97.60 & 142.96 & 195.64 & 72.73 \\
\hline Weighted average & 103.01 & 119.01 & 98.57 & 95.28 & 141.43 & 189.73 & 77.26 \\
\hline Minimum & 68.15 & 94.60 & 65.15 & 65.13 & 89.60 & 186.76 & 45.40 \\
\hline Maximum & 136.50 & 152.27 & 141.64 & 122.61 & 234.32 & 260.80 & 119.16 \\
\hline
\end{tabular}

Economic calculations are not enough in order to make decisions regarding replacement of aged technologies with the new ones. A wider context should be taken into account, considering such factors as energy security, geopolitical and social aspects (Augutis et al. 2012). Multi-criteria decision-making analysis is used for making certain decisions, the methods of which are reviewed in paper of (Zavadskas, Turskis 2011).

\section{Energy production and transportation technologies}

The main and commonly used energy generation technologies in the Country energy infrastructure are presented in this chapter. Photovoltaic and wind electricity generation technologies are not analysed. The reason is the installed capacity of photovoltaic and wind electricity generation technologies is quite small compared with the entire system (in Lithuanian case). The Biomass CHP is not analysed as well. These heat and electricity generation technologies which use renewable energy sources are important and they will be included in the future research. The input-output method is used for modelling concept in the paper. So it allows us to compare the operation of simulation system and real system.

The technology that is used to generate electricity and heat could be described by the following expression:

$$
T c h_{i}=\left(P_{i}, Q_{i}, \eta_{e l}, \eta_{h}\right),
$$

where: $P_{i}$ - the installed electric capacity in to $i^{\text {th }}$ technology (MW); $Q_{i}$ - the installed thermal capacity in to $i^{\text {th }}$ technology (MW); $\eta_{e l}$ - the efficiency of primary energy conversion for electricity using main fuel; $\eta_{h}$ - the efficiency of primary energy conversion for heat using main fuel. 
The main parameters characterizing the energy-generating technologies are:

- thermal capacity of plant $Q_{i}(\mathrm{MW})$;

- electrical capacity of plant $P_{i}(\mathrm{MW})$;

- efficiencies, which convert the primary energy source of heat energy and electrical energy $0<\eta_{e l}<1$ and $0<\eta_{h}<1$;

- coefficient indicating power / heat production ratio $0<\sigma_{i}<1$;

- generation technology uses fuel $f$ (tone of oil equivalent, toe);

- the reliability indicator $r_{i}$.

The energy generation technology could be characterized by the following parameters:

$$
\vec{E}_{i}=F\left(T_{i}, f_{j i}, \alpha_{i}, d_{z i}\right)=\left\{p_{i}, q_{i}\right\}
$$

where: $i$ - the type of technology, $i=1, \ldots, N ; N$ - number of CHP, PP, BH and HP of considered energy system; $p_{i}$ - the quantity of generated electrical power $\mathrm{MWh} ; q_{i}$ - the quantity of generated heat MWh; $F(\cdot)$ - functional dependency describe generation technology work; $T_{i}$ - the technical characteristics of $i^{\text {th }}$ generation technology; $f_{j i}$ - the quantity of $j^{\text {th }}$ fuel type provided to $i^{\text {th }}$ generation technology; $\alpha_{i}-$ the availability rate of $i^{\text {th }}$ technology; $d_{z i}-z^{\text {th }}$ consumer demand of $i^{\text {th }}$ technology.

The generation technologies of heat and electricity are described (characterized) in more details.

\subsection{Heat generation by Fuel-based boilers}

This type of heat generation technology is mostly used for satisfaction of low heat emission demand of local consumers, when there is no district heating network. The structural scheme of this energy generation technology is shown in Fig. 2.

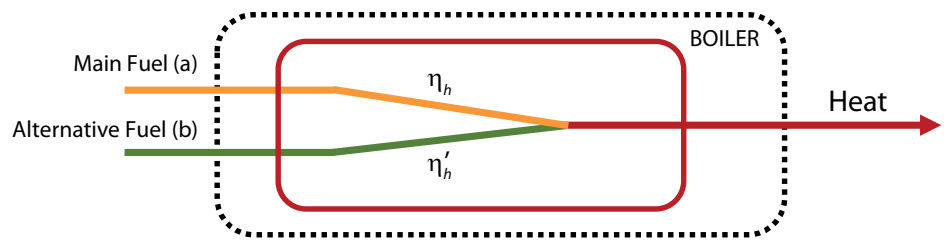

Fig. 2. Fuel-based boiler - house technology

\subsection{Cogeneration (combined heat and electricity production power plants) technology}

CHP technology is divided into several types according to production output and the thermal power and electric power of power plant. The first type of this technology is CHP with back-pressure units. This technology is characterized by the main generation production and it is heat (the primary energy converted with certain efficiencies into output product). In this case steam produced in steam boiler drives steam turbine and generator and produces 
electricity. The rest of thermal energy from steam leaving steam turbine is taken by industrial or residential consumers. The electrical power during the generation process is a by-product. The main fuel in this technology could be natural gas and the alternative fuel could be oil or biomass. The structural scheme of this energy generation technology is shown in Fig. 3.

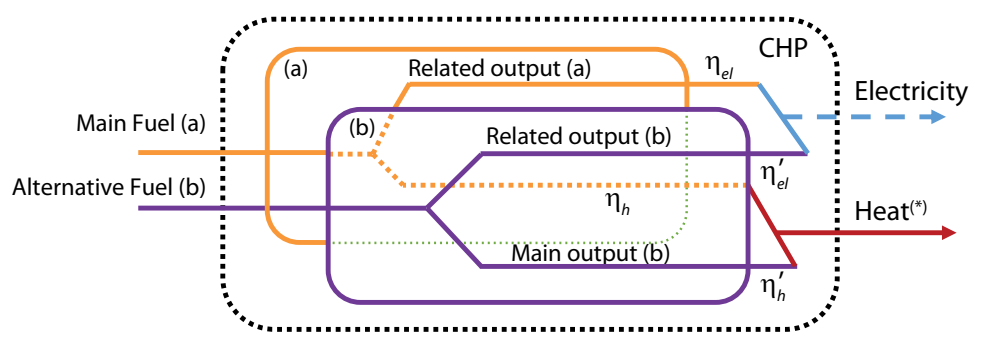

Fig. 3. CHP with back-pressure units:

$\mathrm{a}$ - generation technology with main fuel; $\mathrm{b}$-generation technology with alternative fuel;

* - main products; $\eta_{e l}$ - the efficiency of primary energy conversion for electricity using main fuel;

$\eta_{h}$ - the efficiency of primary energy conversion for heat using main fuel; $\eta_{e l}^{\prime}$ - the efficiency of primary energy conversion for electricity using alternative fuel; $\eta_{h}^{\prime}$ - the efficiency of primary energy conversion for heat using alternative fuel.

The combined heat and power plants generally are built near the cities. So this heat and power generation plants are oriented in local customers demand. As well as these plants have much higher efficiency of utilization of primary energy-fuel, they replace condensing power plant and boiler-house that correspondingly serves for electricity and heat production. Therefore, these CHP generation technologies are assumed to simplify in our model.

The other type of this technology is CHP with extraction units. This opportunity enables to generate electricity production without heat supply. This type of production technology is characterized by a higher electric power output than the thermal power.

The total CHP efficiency is (Secretariat 2004):

$$
\eta_{\mathrm{CHP}}=\frac{P_{i}+Q_{i}}{F-F_{n o n-\mathrm{CHP}}},
$$

the efficiency of the main (electricity) output:

$$
\eta_{e l}=\frac{P_{i}}{\frac{P_{i}+Q_{i}}{\eta_{\mathrm{CHP}}}}
$$

and the efficiency of related (heat) output:

$$
\eta_{h}=\frac{Q_{i}}{\frac{P_{i}+Q_{i}}{\eta_{\mathrm{CHP}}}}
$$

where: $F$ - used fuel for generation (t.o.e.); $F_{n o n-\mathrm{CHP}}-$ used fuel for generation in not CHP mode (t.o.e.); $Q_{i}$ - the amount of generated heat (MWh); $P_{i}$ - the amount of generated electricity (MWh). 
We assumed that the main product produced by this technology is heat. The electricity power in this case is generated as a by-product. Another assumption in CHP generation technology approach is that in this technology one main fuel is used for generation process (for instance, natural gas, biomass, etc.) and the alternative fuels are used in the case when supply of main fuel are limited or not supplied. The structural scheme of this energy generation technology is shown in Fig. 3.

\subsection{Hydro power plant}

Hydroelectric power generation technology can be defined using the following expression:

$$
P_{i}=F\left(Q_{w} ; H_{h} ; \eta\right)
$$

where: $P_{i}$ - generated output power $(\mathrm{MWh}) ; Q_{w}$ - water flow $\left(\mathrm{m}^{3} / \mathrm{s}\right) ; H_{h}$ - hydraulic head height $(\mathrm{m}) ; \eta$ - efficiency.

\subsection{Gas pipeline supply system}

Natural gas as main fuel is used in most of main energy generation technologies in the heat and electricity systems. Gas pipeline supply system is characterized by pipeline flow, the pressure in the pipeline and pipeline reliability. In real situation gas supply by pipelines network is quite difficult to assess. The reason is that Country gas pipeline network could be a very difficult structure, where pipeline loops, different sections of the pipeline may have different diameters. In the paper we assumed that gas supply network is grouped by segments. The part of pipeline from the Country border with other country to the different generation technologies that used gas is denoted as the segment of pipeline. Some segments of pipeline are composed of the same parts of pipeline. The segment of pipeline could be composed of different diameter of pipelines. This method has been simplified to facilitate the calculation of the flow rate capacity assessment.

To solve the difficulty of different pipeline diameter (as shown in the Fig. 4) could be possible by using the following expressions (Chen 1999):

$$
\begin{gathered}
C_{i}=11.75 L_{i}^{0.5} D_{i}^{0.5} R e_{i}^{-0.1 ;} \\
C_{1}^{\prime}=C_{1}\left(\frac{D_{1}}{D_{2}}\right)^{2} ; \\
L^{\prime}=\left(\frac{C_{1}^{\prime}}{11.75 D_{2}^{0.5} R e_{2}^{-0.1}}\right)^{2} ; \\
C_{2}=11.75\left(L_{2}+L^{\prime}\right)^{0.5} D_{2}^{0.5} R e_{2}^{-0.1,}
\end{gathered}
$$

where: $C_{i}$ - length of the mixed oil products at the end point if $i^{\text {th }}$ pipeline segment, $\mathrm{m} ; D_{i}-$ pipe diameter of $i^{\text {th }}$ pipeline segment, $\mathrm{m} ; L^{\prime}-$ transmission distance of $i^{\text {th }}$ pipeline segment, $\mathrm{m}$; $R e_{i}-$ Reynolds number of $i^{\text {th }}$ pipeline segment. 
a)

b)
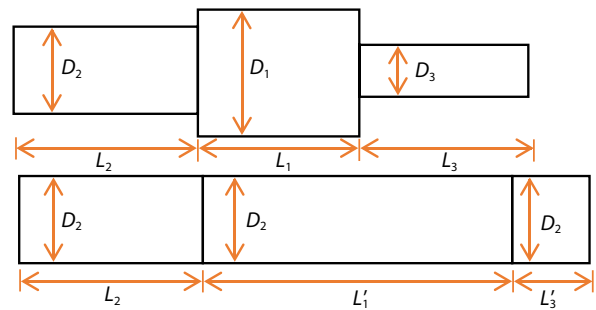

Fig. 4. a - segment, $\mathrm{b}$ - pipeline equivalent to real pipeline

The quantity of natural gas which is provided to the generation technology could be estimated by the following equation (Menon 2005):

$$
Q_{i}=a \cdot E \cdot S G^{-0.425} \cdot D^{2.725} \cdot\left(\frac{\left(P_{\text {in }}^{2}-P_{\text {out }}^{2}\right)}{L}\right)^{0.575},
$$

where: $a=2.489 \cdot 10^{-9} ; Q_{i}$ - flow rate of $i^{\text {th }}$ pipeline (millions of $\mathrm{m}^{3} / \mathrm{hr}-\mathrm{mm}^{3} / \mathrm{hr}$ ); SG - specific gravity of the gas; $E$ - efficiency; $D$ - internal pipeline diameter $(\mathrm{mm}) ; L$ - pipeline length $(\mathrm{km})$; $P_{\text {in }}$ - inlet pressure (Bar); $P_{\text {out }}$ - outlet pressure (Bar).

\section{Assessment of functionality and criticality}

The functionality and criticality of infrastructure are assessed using a functional analysis approach. The functionality of elements could be defined for two issues:

- The functionality of elements could be described, how much quantitatively $i^{\text {th }}$ element could satisfy the demand of other system elements.

- The technical functionality of elements could be described as ability of the $i^{\text {th }}$ element to satisfy the actual demand; this ability is expressed as a percentage. This type of element functionality, could tell what is the technical ability of the $i^{\text {th }}$ element to satisfy the demand.

The reduction of the functionality of one element could lead the operation of other elements. Thus this behaviour must be taken into account performing the assessment of functionality of all system or other separate elements. Functionality $f$ and technical functionality $f T$ of the $i^{\text {th }}$ element depending on other elements demand could be estimated by the following equations (when the $k^{\text {th }}$ element was assumed to be out of order):

and

$$
f_{i}^{(k)}(t)=1-\frac{\sum_{j=1, j \neq i, k}^{N} D_{j i}(t)-\sum_{j=1, j \neq i, k}^{N} S_{i j}(t)}{\sum_{j=1, j \neq i, k}^{N} D_{j i}(t)}, i=1,2, \ldots, N
$$

$$
f T_{i}^{(k)}(t)=1, D_{j i}(t) \leq \operatorname{Tech} A_{i j}(t) .
$$




$$
f T_{i}^{(k)}(t)=1-\frac{\sum_{j=1, j \neq i, k}^{N} D_{j i}(t)-\sum_{j=1, j \neq i, k}^{N} \operatorname{Tech}_{i j}(t)}{\sum_{j=1, j \neq i, k}^{N} D_{j i}(t)}, D_{j i}(t)>\operatorname{Tech} A_{i j}(t), i=1,2, \ldots, N,
$$

where: $(k)-k^{\text {th }}$ index means, that $k^{\text {th }}$ element is out of order; $D_{i j}(t)$ - the quantity of demand of resource from $i^{\text {th }}$ element to $j^{\text {th }}$ element at time moment $t ; S_{i j}(t)$ - the quantity of resource which $i^{\text {th }}$ elements could supply to $j^{\text {th }}$ element at time moment $t$; Tech $A_{i j}(t)-i^{\text {th }}$ element ability to satisfy demand of $j^{\text {th }}$ element at time moment $t$.

The elements within infrastructure may not be equally important, therefore, they should be ranked according to the number of served consumers.

The supplier, which has the greatest number of consumers, gets the highest weighted coefficient. The weighted coefficient is defined by $\alpha_{i}$ that satisfies equality:

$$
\sum_{i=1}^{N} \alpha_{i}=1
$$

In the case of equivalent elements, the weighted coefficients are $\alpha_{i}=1 / N, N$ - number of suppliers.

Then functionality indicator of infrastructure system could be estimated using the following formula:

$$
S f^{(k)}(t)=\sum_{i=1} f_{i}^{(k)}(t) \cdot \alpha_{i}, i=1,2, \ldots, N,
$$

where: $(k)-k^{\text {th }}$ index means, that $k^{\text {th }}$ element is out of order; $f_{i}(t)-$ the estimate of the $i^{\text {th }}$ element functionality; $\alpha_{i}$ - the weighted coefficient of $i^{\text {th }}$ element.

The reliability indicator for final consumer $c f$ that shows how much the demand of energy is satisfied $(0 \leq c f \leq 1)$ :

$$
c f_{i}^{(k)}(t)=1-\frac{\sum_{j=1, j \neq k}^{N} N S E_{j i}(t)}{\sum_{j=1, j \neq k}^{N} D_{i j}(t)} i=1,2, \ldots, M,
$$

where: $M$ - number of the final consumers in the energy system; $N S E_{j i}(t)$ - not supplied energy from $j^{\text {th }}$ element for demands of $i^{\text {th }}$ consumer at time moment $t ; D_{i j}(t)$ - the quantity of demand of resource from $i^{\text {th }}$ element to $j^{\text {th }}$ element at time moment $t$.

As the review of the literature shows there is no general understanding of what criticality of infrastructure is. This issue faces main challenges:

- the subjective standpoint on criticality leading to the identification of different types of criticality (for instance, performing structural analysis, the criticality is defined using the number of connections of element);

- the evolution of a critical situation (evaluation of the cascade effect of disturbance);

- the necessity to indicate the part of infrastructure for assessing its criticality. 
The criticality of the $k^{\text {th }}$ element could be assessed with regards to the functionality of all system $S f^{(k)}(t)$ that is obtained when the $k^{\text {th }}$ element was assumed to be out of order. The selection of elements with the biggest impact on system functionality is performed. Or the other way, the criticality of the $k^{\text {th }}$ element may be estimated using the reliability indicators of final consumers obtained in case when $k^{\text {th }}$ element is out of order:

$$
C^{(k)}(t)=1-\sum_{i=1}^{M} c f_{i}^{(k)}(t) \cdot \beta_{i} k=1,2, \ldots, N,
$$

where: $N$ - number of the elements in the energy system; $c f_{i}^{(k)}(t)$ - the reliability indicator that shows how much the energy demand is satisfied for the $i^{\text {th }}$ element; $\beta_{i}$ - the weighted coefficient of the $i^{\text {th }}$ final consumer within system (for instance, weighted coefficients are estimated with regards to the energy demand of consumer, and they satisfy equality $\beta_{1}+\ldots+\beta_{M}=1$; $M$ - number of the final consumers in the energy system).

For instance, $C^{(k)}(t)=1$ means that disruption of the $k^{\text {th }}$ element work stops the operation of all energy infrastructure at time $t$.

\section{Assessment model of infrastructure system}

The energy infrastructure system could be presented schematically: indicating heat and electricity systems and how they are related. E.g. Lithuanian case is presented in Fig. 5.

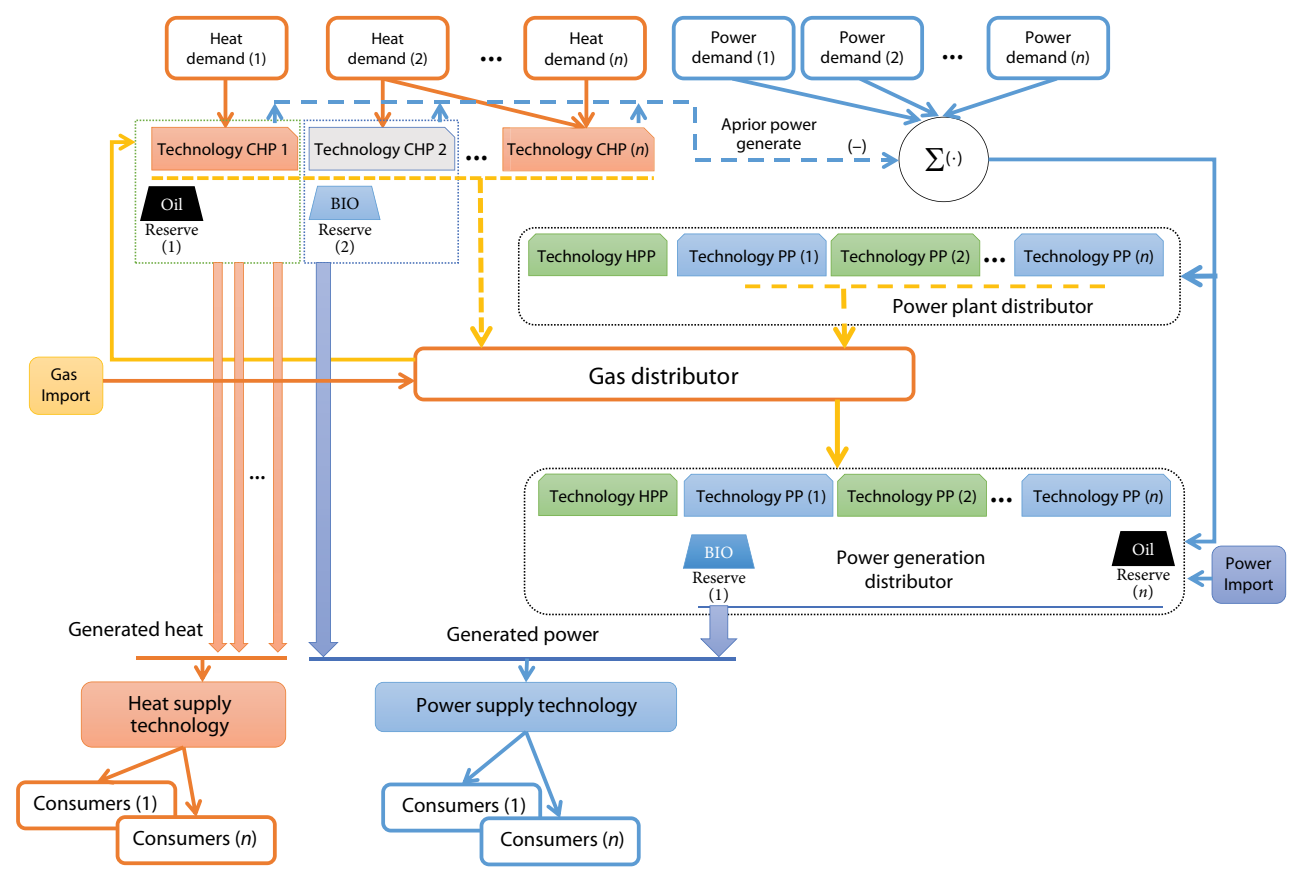

Fig. 5. Scheme of energy infrastructure (Lithuanian case) 
The energy system is modelled in discrete time (e.g. year, quarter of a year, month, etc.). It is possible to assume that the demand for energy is constant during discrete time interval:

$$
D_{E_{i}}(t)= \begin{cases}D_{E_{1}}, & t \in h_{1(k)}, \\ D_{E_{2}}, & t \in h_{2(k)}, \\ D_{E_{3}}, & t \in h_{3(k)}, \\ D_{E_{4}}, & t \in h_{4(k)},\end{cases}
$$

where: $D_{E_{i}}$ - the demand of energy of $i^{\text {th }}$ technology at time $t ; h_{1(k)}, h_{2(k)}, h_{3(k)}, h_{4(k)}$ - quarters of a year; $k$ - the index of a year.

The local heat demands, which could be made of one or more heat generation technologies $\vec{E}_{i}$, are used as input data in the energy systems assessment model. The heat demand is transferred to each generation technology in the beginning of each cycle. If there is a central heating network with multiple heats generating technologies, the heat demand is transferred for a logic model element, which selects the generation technology using the optimization strategy (example: minimal pollution, minimal cost, maximum efficiency $\eta_{h}$, etc.). Some of the heat generation technologies, depending on the generation type, during heat generation, as main production, generated electricity power as a by-product. A certain heat generation technology uses one type of fuel as a main fuel and has a reserve fuel. The estimated fuel demand $D_{F_{i}}$ (Eq. (19)), according the heat demand of each technology, is transferred to a logic fuel distribution element. The total demand of fuel is distributed for generation technologies, according to the strategy (example: technological priorities set out by law, generation efficiency, etc.), by this logic element and it is transferred for fuel supply technologies:

$$
D_{F}(t)=\sum_{i} D_{F_{i}}(t)
$$

The amount of gas, considering to the demands of generation technologies, is supplied by fuel supply technologies. Then the amount of generated heat and generated power are calculated according to the availability of technology.

Otherwise, when generating technologies do not get the required amount of fuel $D_{F_{i}}>F_{i}^{*}$ according to the relevant fuel type and fuel reserve was not enough, not supplied heat quantity is estimated by generation technologies:

$$
N_{-} S_{-} E_{h}^{j}(t)=D_{h}^{j}(t)-\sum_{k} \vec{E}_{i}^{j}(t) .
$$

In this case, the amount of not generated electricity is calculated as well. The alternative fuel supply is provided in the model. The total electricity demand is used as input date in the model:

$$
D_{e l}(t)=\sum_{k} D_{e l_{k}}(t)
$$

The power grids are integral. This allows the supplement of electricity for consumers using different transportation roads. For this reason, electricity generation is combined in one system object. All generators in the power grid are used for electricity generation. This one energy system object is composed of different electricity generation technologies and 
their work activities are defined in the governing documents. Electricity generation technologies are used according with the priorities in the energy simulation model. We made the assumption that all generated power of hydropower plant and CHP are used to satisfy consumers' demand. The system electricity generation distribution element defines the load level of electricity generation technologies according to the main type of fuel which had been supplied and the amount of the available alternative fuel in reserves. In the case when consumer demand of electricity could not be satisfied by power grid generators, concerning shortages of fuel or other reasons, model applies for the electricity amount to the import technology. This technology is used to ensure electricity demand of consumer as technical system element with his reliability index. In the case when the consumer demand for electricity could not be satisfied by all energy generation technologies:

$$
D_{e l}(t)>\sum_{i} \vec{E}_{i}(t)+I_{e l}(t)
$$

the amount of not supplied electricity is calculated:

$$
N_{-} S_{-} E_{e l}(t)=D_{e l}(t)-\left(\sum_{k} \vec{E}_{i}(t)+I_{e l}(t)\right) \text {. }
$$

Natural gas import data also are used in the primary model data.

\section{Numerical example for modelling Lithuanian energy infrastructure}

The method for the assessment of infrastructure functionality and criticality (presented in chapter 3) was applied for the energy infrastructure of Lithuania. The pilot numerical calculations were performed for the part of Lithuanian energy infrastructure (presented in Fig. 1). The simplified scheme of the Lithuanian gas supply and heat or electricity generation model is shown in Fig. 6.

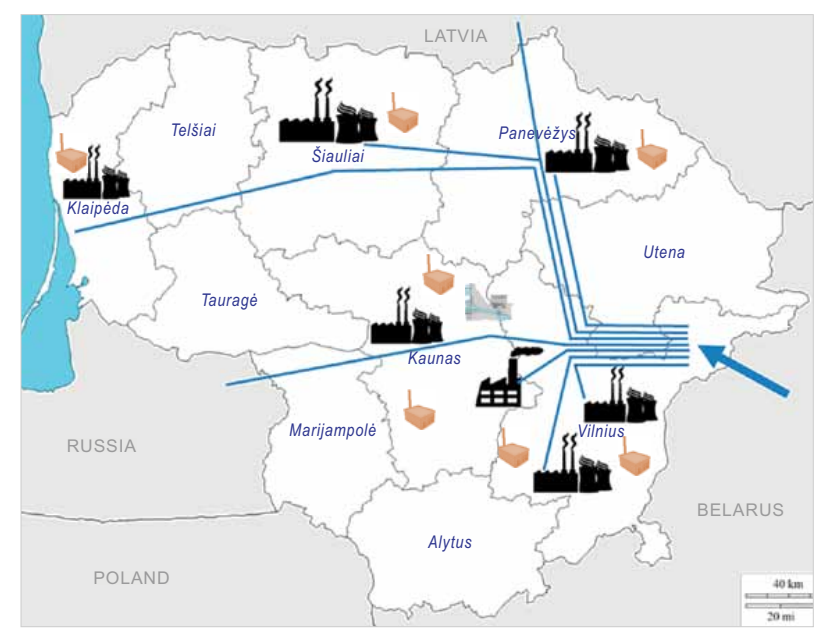

Fig. 6. The scheme of Lithuanian gas supply and heat and electricity generation infrastructure 
Several assumptions were made for considering energy infrastructure:

1. Lithuanian heat generation system is composed of seven combined heat and power plants and thirty boiler houses. They are located in bigger Lithuanian cities;

2. The heat generation technologies are as described in Section 2;

3. Electricity import is not analysed;

4. The main fuel is gas, the alternative fuel is oil. The reserve fuel is included in all CHP. The list of heat generation technologies (CHP and boiler hoses) is shown in Table 2. The list of power generation technologies is shown in Table 3.

Table 2. The list of summed heat generation technology of model

\begin{tabular}{lcccc}
\hline & $\begin{array}{c}\text { The quantity of } \\
\text { CHP }\end{array}$ & $\begin{array}{c}\text { The quantity } \\
\text { of } \mathrm{BH}\end{array}$ & $\begin{array}{c}\text { Sum installed power } \\
\text { capacity } \\
(\mathrm{MW})\end{array}$ & $\begin{array}{c}\text { Sum installed heat } \\
\text { capacity } \\
(\mathrm{MW})\end{array}$ \\
\hline Kaunas & 1 & 7 & 170 & 1028 \\
\hline Klaipèda & 1 & 4 & 10.8 & 999 \\
\hline Mažeikiai & 1 & 2 & 160 & 701 \\
\hline Panevė̌zys & 1 & 8 & 35 & 691 \\
\hline Šiauliai & 1 & 5 & 3 & 2740 \\
\hline Vilnius & 2 & 4 & 384 & \\
\hline
\end{tabular}

Table 3. The list of electricity generation technology of model

\begin{tabular}{lcc}
\hline & $\begin{array}{c}\text { Installed power capacity } \\
(\mathrm{MW})\end{array}$ & $\begin{array}{c}\text { Installed Heat capacity } \\
(\mathrm{MW})\end{array}$ \\
\hline Kaunas Hydro power Plant & 100.8 & 0 \\
\hline $\begin{array}{l}\text { Kruonis Pumped Storage } \\
\text { Hydroelectric Plant }\end{array}$ & 800 & 0 \\
\hline Lithuanian Power Plant & 1800 & 1752 \\
\hline
\end{tabular}

* This pump storage power plant works in reserve mode.

The model of energy system is comprised of 37 heat generation technologies, 1 power plant, 2 hydro power plant, 8 segments of gas network and 15 sub segments of gas network. The simulation is performed when one element of energy system is out of order (in this analysis the system is comprised of 63 elements). As a result, we are receiving the criticality value of each 63 elements. Some assumptions for system modelling:

- Lithuanian gas network was divided into the pipeline segments;

- each segment of gas network is connected to separate heat generation technology.

Thus, eight segments of gas network with different lengths and diameters are analysed in numerical example. As shown in Fig. 6, all segments of gas network have common part of pipeline, let say symbol SG represents this part. The capacities of pipeline segments transmission are shown in Table 4.

The demands of heat used in the model are shown in Table 5. 
Table 4. The list of the capacities of pipeline segments transmission

\begin{tabular}{lc}
\hline \multicolumn{1}{c}{ Segment number } & The capacity $\mathrm{Mm}^{3} /$ quarterly period \\
\hline SG1:form SG to Klaipèda & 150.56 \\
\hline SG2:form SG to Mažeikiai & 32.85 \\
\hline SG3:form SG to Šiauliai & 100.37 \\
\hline SG4:form SG to Panevėžys & 250.93 \\
\hline SG5:form SG to Kaunas & 372.3 \\
\hline SG6:form SG to Elektrenai & 748.25 \\
\hline SG7:form SG to Vilnius2 & 394.2 \\
\hline SG8:form SG to Vilnius3 & 20.98 \\
\hline
\end{tabular}

Table 5. Heat and electricity demands of Lithuania model

\begin{tabular}{lcccc}
\hline \multicolumn{1}{c}{ City } & Demand, TWh & 1 year & 2 year & 3 year \\
\hline Kaunas & Heat & 1.579 & 1.697 & 1.52 \\
\hline Klaipèda & Heat & 0.99 & 1.087 & 0.95 \\
\hline Mažeikiai & Heat & 0.164 & 0.18 & 0.16 \\
\hline Panevěžys & Heat & 0.13 & 0.85 & 0.767 \\
\hline Šiauliai & Heat & 0.5168 & 0.5563 & 0.49 \\
\hline Vilnius & Heat & 2.9376 & 3.063 & 2.75 \\
\hline Lithuania & Power & 9.637 & 9.677 & 9.639 \\
\hline
\end{tabular}

The calculations are intended for the determination of impact on the Lithuanian heat supply infrastructure system, when the activity of the considered system is influenced by the disturbance(s).

The disturbances in the infrastructure might occur due to:

- the disruption of gas supply networks elements work;

- the disruption of CHP operation;

- the disruption of fuel reserve operation.

The operation of energy infrastructure was simulated in different disturbance scenarios. The main aim of simulations is to assess, how particular element of the energy system affects the energy system criticality. In each scenario one element of energy system is out of order and then system criticality is calculated. The influence of disturbances on the energy infrastructure functionality is assessed by calculating system functionality indicators (15) and reliability indicators for final consumers (16). The obtained indicators are used to assess the criticality (17) of infrastructure elements. The obtained results may be used to identify the most critical scenario (or element of infrastructure).

Results of nearly two-thirds of the scenarios (41 from 63) showed that the criticality of the elements is zero. It means that when element of energy system is out of order, it practically does not affect system operation. This situation was most often, because the generation technologies were diversified for consumer in Lithuanian energy system. In Table 6 the results are presented with scenario with non-zero elements impact on Lithuanian energy system functionality. 
Table 6. The list of not zero impact disturbance scenarios

\begin{tabular}{|c|c|c|}
\hline No. of scenario & Out of order & Consequences \\
\hline SC38 & EL_PP & EL_PP is out of order \\
\hline SC41 & $\begin{array}{l}\text { The common part } 1 \text { of } \\
\text { gas pipeline segments }\end{array}$ & No gas supply to Klaipeda KL_BH_2, KL_BH_3, KL_BH_4 \\
\hline SC42 & $\begin{array}{l}\text { The common part } 2 \text { of } \\
\text { gas pipeline segments }\end{array}$ & No gas supply to Klaipèda KL_CHP_1, KL_BH_1 \\
\hline SC43 & $\begin{array}{l}\text { The common part } 3 \text { of } \\
\text { gas pipeline segments }\end{array}$ & No gas supply to Mažeikiai M_CHP_1, M_BH_1, M_BH_2 \\
\hline SC44 & $\begin{array}{l}\text { The common part } 4 \text { of } \\
\text { gas pipeline segments }\end{array}$ & $\begin{array}{l}\text { No gas supply to all CHP and boiler house of Klaipeda } \\
\text { and Mažeikiai }\end{array}$ \\
\hline SC45 & $\begin{array}{l}\text { The common part } 5 \text { of } \\
\text { gas pipeline segments }\end{array}$ & No gas supply to Šiauliai S_BH_3, S_BH_4, S_BH_5 \\
\hline SC46 & $\begin{array}{l}\text { The common part } 6 \text { of } \\
\text { gas pipeline segments }\end{array}$ & $\begin{array}{l}\text { No gas supply to Šiauliai S_CHP_1, S_BH_1, S_BH_2, } \\
\text { S_BH_3, S_BH_4, S_BH_5 }\end{array}$ \\
\hline SC47 & $\begin{array}{l}\text { The common part } 7 \text { of } \\
\text { gas pipeline segments }\end{array}$ & $\begin{array}{l}\text { No gas supply to all CHP and boiler house of Klaipeda, } \\
\text { Mažeikiai and Šiauliai }\end{array}$ \\
\hline SC48 & $\begin{array}{l}\text { The common part } 8 \text { of } \\
\text { gas pipeline segments }\end{array}$ & $\begin{array}{l}\text { No gas supply to Panevė̌zys P_BH_5, P_BH_6, P_BH_7, } \\
\text { P_BH_8 }\end{array}$ \\
\hline SC49 & $\begin{array}{l}\text { The common part } 9 \text { of } \\
\text { gas pipeline segments }\end{array}$ & No gas supply to all CHP and boiler house of Panevezžys \\
\hline SC50 & $\begin{array}{l}\text { The common part } 10 \text { of } \\
\text { gas pipeline segments }\end{array}$ & $\begin{array}{l}\text { No gas supply to all CHP and boiler house of Klaipèda, } \\
\text { Mažeikiai, Šiauliai, Panevėžys }\end{array}$ \\
\hline SC51 & $\begin{array}{l}\text { The common part } 11 \text { of } \\
\text { gas pipeline segments }\end{array}$ & No gas supply to Kaunas K_BH_3, K_BH_4, K_BH_7 \\
\hline SC52 & $\begin{array}{l}\text { The common part } 12 \text { of } \\
\text { gas pipeline segments }\end{array}$ & $\begin{array}{l}\text { No gas supply to Kaunas } \mathrm{K} \_B H \_1, \mathrm{~K} \_B H \_2, \mathrm{~K} \_B H \_3 \text {, } \\
\text { K_BH_4, K_BH_5, K_BH_6, K_BH_7 }\end{array}$ \\
\hline SC53 & $\begin{array}{l}\text { The common part } 13 \text { of } \\
\text { gas pipeline segments }\end{array}$ & No gas supply to all CHP and boiler house of Kaunas \\
\hline SC54 & $\begin{array}{l}\text { The common part } 14 \text { of } \\
\text { gas pipeline segments }\end{array}$ & No gas supply to Elektrenai EL_PP \\
\hline SC55 & $\begin{array}{l}\text { The common part } 15 \text { of } \\
\text { gas pipeline segments }\end{array}$ & $\begin{array}{l}\text { No gas supply to all CHP and boiler house of Kaunas } \\
\text { and Elektrenai power plant }\end{array}$ \\
\hline SC58 & $\begin{array}{l}\text { The common part } 18 \text { of } \\
\text { gas pipeline segments }\end{array}$ & No gas supply to Vilnius V_BH_3, V_BH_4 \\
\hline SC59 & $\begin{array}{l}\text { The common part } 19 \text { of } \\
\text { gas pipeline segments }\end{array}$ & No gas supply to Vilnius V_CHP_3 \\
\hline SC60 & $\begin{array}{l}\text { The common part } 20 \text { of } \\
\text { gas pipeline segments }\end{array}$ & $\begin{array}{l}\text { No gas supply to Vilnius V_BH_1, V_BH_2, V_BH_3, } \\
\text { V_BH_4 }\end{array}$ \\
\hline SC61 & $\begin{array}{l}\text { The common part } 21 \text { of } \\
\text { gas pipeline segments }\end{array}$ & No gas supply to all CHP and boiler house of Vilnius \\
\hline SC62 & $\begin{array}{l}\text { The common part } 22 \text { of } \\
\text { gas pipeline segments }\end{array}$ & $\begin{array}{l}\text { No gas supply to all CHP and boiler house of Kaunas, Vilnius } \\
\text { and Elektrenai power plant }\end{array}$ \\
\hline SC63 & $\begin{array}{l}\text { The common part } 23 \text { of } \\
\text { gas pipeline segments }\end{array}$ & It disconnected all gas network segments \\
\hline
\end{tabular}

Where: SC - scenario number; $\mathrm{BH}$ - boiler house; CHP - Combined heat and electricity production power plants; $\mathrm{PP}$ - power plant. 


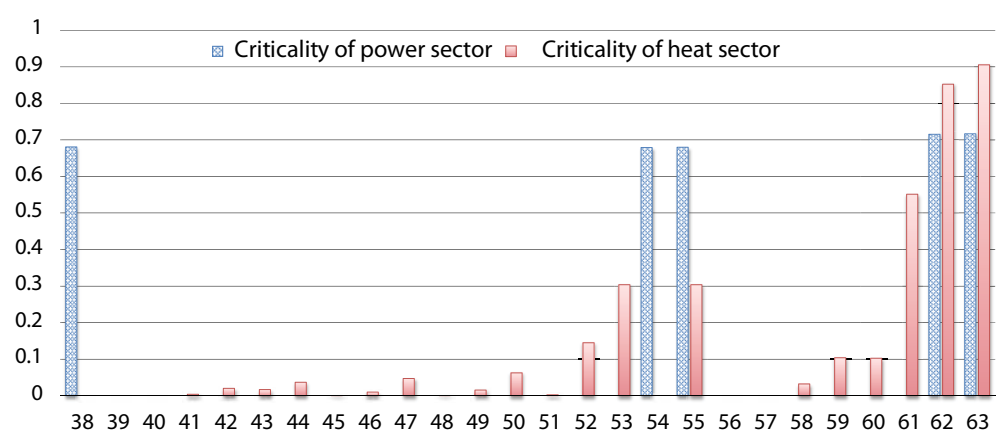

Fig. 7. The criticality of elements in the considered scenarios

An important (non-zero impact) numerical value of the elements in the considered scenarios is presented in Fig. 7.

The criticality of scenarios submitted in Table 6 are presented in Fig. 7.

As shown in Figure 7, the elements of gas supply system are the most critical and have major impact on energy system functionality. The reason is that natural gas as main fuel is used in most heat and electricity generation technologies in Lithuanian energy system, and gas pipeline systems are not annular.

The most critical scenario is SC63 and the criticality value of this scenario is 0.91 (the criticality value is from interval $[0 ; 1]$ ). It showed how the disruption of the main gas supply to Lithuanian pipeline (when gas supply to Lithuania is interrupted) affected the Lithuanian energy system.

The other most critical scenarios for heat and electricity systems are SC55, SC61, SC62. In all of these scenarios, the gas supply is disrupted to larger Lithuanian cities (Vilnius, Kaunas, Elektrènai), and natural gas is used as main fuel in heat generations technologies on those cities.

The most critical scenario for electricity system is SC38, when Elektrenai power plant is out of order (the value of this scenario is 0.68 ). Therefore Elektrenai power plant is one of the main electricity generation power plants in Lithuania (when electricity import is not analysed). The other most critical scenario for electricity system scenario is SC54, when gas supply to Elektrènai power plant is disrupted (the value of this scenario is 0.67 ).

\section{Conclusions}

The method of assessment of infrastructure criticality is developed. The models of energy infrastructure are created, which cover main elements of energy infrastructure, the functions of these elements and relations with other elements of infrastructure.

The criticality of element is defined as the out of order element influence to the satisfaction of the demand of the consumers.

The developed method is applied for the criticality assessment of Lithuanian energy infrastructure. Lithuanian energy sectors are analysed as a system of 63 elements. It was assessed that 41 elements did not directly affect the satisfaction of consumer demand. It means that the 
energy infrastructure over capacity is sufficient to satisfy the consumer demand. The loss of other elements influences limitation of the system ability to satisfy the demand of consumers.

The most criticality element of Lithuanian energy infrastructure is the main pipeline for gas import to Lithuania. The criticality value of this element for heat system is 0.91 (the criticality value is from interval $[0 ; 1]$ ) and for electricity system is 0.72 (see scenario SC63).

With regard to the obtained results it could concluded that gas supply system is important (critical) for heat and electricity system of Lithuania. The parts of gas pipeline, which are near Vilnius, Elektrenai and Kaunas have high level of criticality (criticality values are from 0.5 to 0.68$)$.

\section{Acknowledgement}

This research was funded by the Grant (No. ATE-04/2012) from the Research Council of Lithuania.

\section{References}

Amouzandeh, A.; Moser, H.; Ring, T.; Zeiml, M.; Lackner, R.; Mang, H. A. 2011. Holistic analysis of underground infrastructure subjected to fire, Procedia Engineering 14: 41-51. http://dx.doi.org/10.1016/j.proeng.2011.07.005

Augutis, J.; Matuzienè, V. 2012. Tikimybinis energetinio saugumo vertinimas. Kauno šilumos tiekimo rinkos analize, Energetika 58(2): 66-76. http://dx.doi.org/10.6001/energetika.v58i2.2339

Augutis, J.; Krikštolaitis, R.; Martišauskas, L.; Peciulyte, S. 2012. Energy security level assessment technology, Applied Energy 97: 143-149. http://dx.doi.org/10.1016/j.apenergy.2011.11.032

Bompard, E.; Napoli, R.; Xue, F. 2009. Analysis of structural vulnerabilities in power transmission grids, International Journal of Critical Infrastructure Protection 2(1-2): 5-12. http://dx.doi.org/10.1016/j.ijcip.2009.02.002

Brauers, W. K. M.; Kracka, M.; Zavadskas, E. K. 2012. Lithuanian case study of masonry buildings from the Soviet period, Journal of Civil Engineering and Management 18(3): 444-456. http://dx.doi.org/10.3846/13923730.2012.700944

Canto-Perello, J.; Curiel-Esparza, J.; Calvo, V. 2013. Criticality and threat analysis on utility tunnels for planning security policies of utilities in urban underground space, Expert Systems with Applications 40(11): 4707-4714. http://dx.doi.org/10.1016/j.eswa.2013.02.031

Chai, C. L.; Liu, X.; Zhang, W. J.; Baber, Z. 2011. Application of social network theory to prioritizing oil \& gas industries protection in a networked critical infrastructure system, Journal of Loss Prevention in the Process Industries 24(5): 688-694. http://dx.doi.org/10.1016/j.jlp.2011.05.011

Chen, Q. 1999. Calculations on the mixing volume of products pipeline with variable diameter pipes, Gas Storage and Transportation 18: 7-8.

Chou, J.-S.; Ping Tserng, H.; Lin, C.; Yeh, C.-P. 2012. Critical factors and risk allocation for PPP policy: comparison between HSR and general infrastructure projects, Transport Policy 22: 36-48. http://dx.doi.org/10.1016/j.tranpol.2012.05.009

Eusgeld, I.; Kröger, W.; Sansavini, G.; Schläpfer, M.; Zio, E. 2009. The role of network theory and object-oriented modeling within a framework for the vulnerability analysis of critical infrastructures, Reliability Engineering \& System Safety 94(5): 954-963. http://dx.doi.org/10.1016/j.ress.2008.10.011

Hassan, M. N.; Hawas, Y. E.; Maraqa, M. A. 2012. A holistic approach for assessing traffic safety in the United Arab Emirates, Accident Analysis \& Prevention 45: 554-564.

http://dx.doi.org/10.1016/j.aap.2011.09.009 
Holden, R.; Val, D. V.; Burkhard, R.; Nodwell, S. 2013. A network flow model for interdependent infrastructures at the local scale, Safety Science 53: 51-60. http://dx.doi.org/10.1016/j.ssci.2012.08.013

International Energy Agency, N. E. A. 2010. Projected Costs of Generating Electricity 2010.

Yan, G.; Eidenbenz, S.; Thulasidasan, S.; Datta, P.; Ramaswamy, V. 2010. Criticality analysis of Internet infrastructure, Computer Networks 54(7): 1169-1182. http://dx.doi.org/10.1016/j.comnet.2009.11.002

Johansson, J.; Hassel, H.; Zio, E. 2013. Reliability and vulnerability analyses of critical infrastructures: comparing two approaches in the context of power systems, Reliability Engineering \& System Safety 120: 27-38. http://dx.doi.org/10.1016/j.ress.2013.02.027

Kaklauskas, A.; Rute, J.; Zavadskas, E. K.; Daniunas, A.; Pruskus, V.; Bivainis, J.; Gudauskas, R.; Plakys, V. 2012. Passive House model for quantitative and qualitative analyses and its intelligent system, Energy and Buildings 50: 7-18. http://dx.doi.org/10.1016/j.enbuild.2012.03.008

Kjølle, G. H.; Utne, I. B.; Gjerde, O. 2012. Risk analysis of critical infrastructures emphasizing electricity supply and interdependencies, Reliability Engineering \& System Safety 105: 80-89. http://dx.doi.org/10.1016/j.ress.2012.02.006

Menon, E. S. 2005. Gas pipeline hydraulics. Taylor \& Francis. 416 p. http://dx.doi.org/10.1201/9781420038224

Murray, A. T.; Grubesic, T. H. 2012. Critical infrastructure protection: the vulnerability conundrum, Telematics and Informatics 29(1): 56-65. http://dx.doi.org/10.1016/j.tele.2011.05.001

Nan, C.; Eusgeld, I.; Kröger, W. 2013. Analyzing vulnerabilities between SCADA system and SUC due to interdependencies, Reliability Engineering \& System Safety 113: 76-93. http://dx.doi.org/10.1016/j.ress.2012.12.014

Ryu, D. H.; Kim, H.; Um, K. 2009. Reducing security vulnerabilities for critical infrastructure, Journal of Loss Prevention in the Process Industries 22: 1020-1024. http://dx.doi.org/10.1016/j.jlp.2009.07.015

Sabio, N.; Kostin, A.; Guillén-Gosálbez, G.; Jiménez, L. 2012. Holistic minimization of the life cycle environmental impact of hydrogen infrastructures using multi-objective optimization and principal component analysis, International Journal of Hydrogen Energy 37(6): 5385-5405.

http://dx.doi.org/10.1016/j.ijhydene.2011.09.039

Secretariat, C. C. 2004. Manual for determination of combined heat and power (CHP). Standard Number: CWA 45547:2004, CEN/CENELEC, Brussels. 78 p.

Skea, J.; Chaudry, M.; Wang, X. 2012. The role of gas infrastructure in promoting UK energy security, Energy Policy 43: 202-213. http://dx.doi.org/10.1016/j.enpol.2011.12.057

Tanaka, K.; Yoza, A.; Ogimi, K.; Yona, A.; Senjyu, T.; Funabashi, T.; Kim, C.-H. 2012. Optimal operation of DC smart house system by controllable loads based on smart grid topology, Renewable Energy 39(1): 132-139. http://dx.doi.org/10.1016/j.renene.2011.07.026

The Council Of The European Union 2008. Council directive 2008/114/EC of 8 December 2008. Official Journal of the European Union.

Theoharidou, M.; Kotzanikolaou, P.; Gritzalis, D. 2010. A multi-layer criticality assessment methodology based on interdependencies, Computers \& Security 29(6): 643-658.

http://dx.doi.org/10.1016/j.cose.2010.02.003

Trucco, P.; Cagno, E.; De Ambroggi, M. 2012. Dynamic functional modelling of vulnerability and interoperability of critical infrastructures, Reliability Engineering \& System Safety 105: 51-63. http://dx.doi.org/10.1016/j.ress.2011.12.003

Utne, I. B.; Hokstad, P.; Vatn, J. 2011. A method for risk modeling of interdependencies in critical infrastructures, Reliability Engineering \& System Safety 96(6): 671-678. http://dx.doi.org/10.1016/j.ress.2010.12.006

Van Der Vleuten, E.; Lagendijk, V. 2010. Interpreting transnational infrastructure vulnerability: European blackout and the historical dynamics of transnational electricity governance, Energy Policy 38(4): 2053-2062. http://dx.doi.org/10.1016/j.enpol.2009.11.030 
Venckus, N.; Bliudžius, R.; Poderytė, J.; Burlingis, A. 2012. The heating load determination of low energy buildings in northern climate, Journal of Civil Engineering and Management 18(6): 828-833. http://dx.doi.org/10.3846/13923730.2012.720938

Wang, S.; Hong, L.; Chen, X. 2012. Vulnerability analysis of interdependent infrastructure systems: a methodological framework, Physica A: Statistical Mechanics and its Applications 391: 3323-3335.

Wang, S.; Hong, L.; Ouyang, M.; Zhang, J.; Chen, X. 2013. Vulnerability analysis of interdependent infrastructure systems under edge attack strategies, Safety Science 51(1): 328-337. http://dx.doi.org/10.1016/j.ssci.2012.07.003

Wibowo, A.; Mohamed, S. 2010. Risk criticality and allocation in privatised water supply projects in Indonesia, International Journal of Project Management 28(5): 504-513. http://dx.doi.org/10.1016/j.ijproman.2009.08.003

Xia, Y.; Van Ommeren, J. N.; Rietveld, P.; Verhagen, W. 2013. Railway infrastructure disturbances and train operator performance: the role of weather, Transportation Research Part D: Transport and Environment 18: 97-102. http://dx.doi.org/10.1016/j.trd.2012.09.008

Zavadskas, E. K.; Turskis, Z. 2011. Multiple criteria decision making (MCDM) methods in economics: an overview, Technological and Economic Development of Economy 17(2): 397-427. http://dx.doi.org/10.3846/20294913.2011.593291

Zio, E.; Golea, L. R. 2012. Analyzing the topological, electrical and reliability characteristics of a power transmission system for identifying its critical elements, Reliability Engineering \& System Safety 101: 67-74. http://dx.doi.org/10.1016/j.ress.2011.11.009

Juozas AUGUTIS. Dr Habil, Vice-Rector for Science and Research, Prof. of Department of Mathematics and Statistics, Vytautas Magnus University, Chief Research Assoc. of Laboratory of Nuclear Installation Safety, Lithuanian Energy Institute. Doctor Habil of Technological Sciences, 2003, Lithuanian Energy Institute; PhD in Mathematics, 1986, Vilnius University. Employment: Professor (2006), Associate Professor (1990). Publications: author of 1 monograph, over 90 research papers. Honorary awards and membership: prize-winner of the Republic of Lithuania (2005), member of Lithuanian Academy of Sciences. Expert in Lithuanian State Science and Studies Foundation, expert in Science Council of Lithuania. He leads some national and international projects in the area of the energy security as well. Research interests: energy security, reliability theory, risk analysis, probabilistic safety analysis.

Benas JOKŠAS is a PhD student at Lithuanian Energy Institute (Laboratory of Nuclear Installations Safety). His research interest includes critical infrastructure modeling and assessment, risk and reliability assessment of energy systems.

Ričardas KRIKŠTOLAITIS. Dr, Head of Department of Mathematics and Statistics, Vytautas Magnus University, Senior Research Assoc. of Laboratory of Nuclear Installation Safety, Lithuanian Energy Institute. PhD in Mathematics, 2001, Vytautas Magnus University. Employment: Professor (2012), Associate Professor (2007). In 2005 was in 6 month internship in Joint Research Centre Institute for Transuranium Elements, Karlsruhe, Germany. Publications: 1 educational book, over 30 research papers. Research interests: energy security, reliability analysis of power system, statistical data analysis.

Inga ŽUTAUTAITE் was graduated as PhD in Informatics (Vytautas Magnus University, 2010). She is an Associate Professor at the Faculty of Informatics, Vytautas Magnus University, and Research Associate at the Laboratory of Nuclear Installation Safety, Lithuanian Energy Institute. Her scientific interests are system ageing process modelling, risk and reliability assessment of energy systems, Bayesian approach application (with respect of system performance information), and critical infrastructure assessment. 